\title{
PENGEMBANGAN RENCANA PELAKSANAAN PEMBELAJARAN (RPP) MATEMATIKA BERBASIS MODEL LEARNING CYCLE 7E UNTUK SISWA KELAS V SEKOLAH DASAR
}

\author{
Akmal Rijal ${ }^{1}$, Mansyur Romadon Putra ${ }^{2}$ \\ ${ }^{1,2}$ STKIP PGRI Lubuklinggau \\ e-mail: ${ }^{1)}$ akmalrijal3@ gmail.com, ${ }^{2)}$ mans yurromadonputra@ rocketmail.com
}

\begin{abstract}
Abstrak: RPP yang digunakan di sekolah masih belum optimal dalam memfasilitasi pernkembangan peserta didik. Tujuan dari penelitian ini adalah untuk menghasilkan RPP matematika berbasis model learning cycle 7E untuk siswa kelas V sekolah dasar yang valid, praktis, dan efektif. Jenis penelitian ini adalah penelitian pengembangan. Model yang digunakan adalah model pengembangan Plomp, yang terdiri dari tiga tahap: preliminary research, prototyping phase, and assessment phase. Data diperoleh dari uji validitas, kepraktisan dan efektifitas. Validitas data diperoleh dari lembar validasi RPP. Keprakt is an data diperoleh dari lembar angket respon guru, respon peserta didik dan wawancara. Efektifitas diperoleh dari aktivitas peserta didik dan hasil belajar peserta didik. Data yang terkumpul dianalisis secara deskriptif. Hasil penelitian menunjukkan bahwa pembelajaran matematika dengan RPP berbasis model learning cycle 7E memiliki kriteria yang valid dalam hal isi dan konstruksi. RPP sudah praktis baik dari segi keterlaksanaan, kemudahan, dan waktu yang dibutuhkan. RPP juga telah efekt if dari segi aktivitas dan hasil belajar peserta didik dengan nilai rata-rata aktivitas peserta didik meningkat dan ketuntasan belajar, ini berarti perangkat pembelajaran efektif dalam meningkatkan hasil belajar peserta didik. Berdasarkan hasil tersebut dapat disimpulkan bahwa RPP matematika berbasis model learning cycle 7E yang dikembangkan dalam pembelajaran matematika di kelas V SD dapat dinyatakan valid, praktis, dan efektif.
\end{abstract}

Kata Kunci: RPP, Matematika, Learning Cycle $7 \mathrm{E}$

Abstract: RPP used in schools is still not optimal in facilitating student development. The purpose of this study is to produce mathematical lesson plans based on the 7E learning cycle model for elementary school students in grade $\mathrm{V}$ that are valid, practical, and effective. This type of research is development research. The model used is the development model of Plomp, which consists of three stages: preliminary research, prototyping phase, and assessment phase. Data obtained from the validity, practicality and effectiveness test. The validity of the data is obtained from the RPP validation sheet. The practicality of the data was obtained from teacher response questionnaire sheets, student responses and interviews. Effectiveness is obtained from the activities of students and student learning outcomes. The collected data was analyzed descriptively. The results showed that mathematics learning with RPP based on the 7E learning cycle model had valid criteria in terms of content and construction. The lesson plan is practical both in terms of implementation, convenience, and time needed. RPP has also been effective in terms of activities and learning outcomes of students with an average value of increased student activity and mastery learning, this means that learning devices are effective in improving student learning outcomes. Based on these results it can be concluded that the mathematical lesson plan based on the 7E learning cycle model developed in mathematics learning in grade $\mathrm{V}$ elementary school can be declared valid, practical, and effective.

Keywor ds: RPP, Mathematics, 7 E Learning Cycle 


\section{PENDAHULUAN}

Penggunaan perangkat pembelajaran merupakan salah satu faktor penentu keberhasilan sebuah proses pembelajaran. Pengembangan perangkat pembelajaran melihat berbagai komponen yang ada dalam perangkat pembelajaran. Komponen-komponen itu tentunya memiliki pengertian, bentuk, dan format yang berbeda. Trianto (2007:68) menjelaskan bahwa terdapat beberapa komponen perangkat pembelajaran, di antaranya dapat berupa RPP, buku guru, buku siswa, LKS, media, alat evaluasi dan lain sebagainya. Pada penelitian ini, perangkat pembelajaran yang akan dikembangkan yaitu RPP dan LKS.

RPP adalah program perencanaan yang disusun sebagai pedoman pelaksanaan pembelajaran untuk setiap kegiatan proses pembelajaran (Sanjaya. 2009:59). Selanjutnya, menurut Suprihatingrum (2013:114) menyatakan bahwa RPP merupakan penjabaran dari silabus untuk mengarahkan kegiatan belajar peserta didik dalam upaya mencapai kompetensi dasar. Penyusunan RPP juga hendaknya melihat komponen-komponen yang terdapat dalam suatu RPP. Komponen yang menjadi penyusun suatu RPP menurut Peraturan Menteri Nomor 41 tahun 2007. Berdasarkan pendapat di atas, RPP yang akan dikembangkan pada penelitian ini sesuai dengan tahap penyusunan RPP menurut Pemendiknas Nomor 41 tahun 2007 dengan menggunakan model learning cycle 7E.

Mata pelajaran matematika perlu diberikan kepada semua peserta didik mulai dari Sekolah Dasar (SD) sampai sekolah menengah untuk membekali peserta didik dengan kemampuan berpikir logis, analitis, sistematis, kritis, dan kreatif, serta kemampuan bekerjasama. Kompetensi tersebut diperlukan agar peserta didik dapat memiliki kemampuan memperoleh, mengelola, dan memanfaatkan informasi untuk bertahan hidup pada keadaan yang selalu berubah, tidak pasti, dan kompetitif (Depdiknas, 2006: 416).

Penggunaan perangkat Pembelajaran matematika di SD sangat penting karena perangkat pembelajaran dapat meningkatkan kemampuan peserta didik dalam memecahkan masalah, menggunakan kemampuan berfikir kreatif, kritis serta mencari informasi, melakukan investigasi, menarik kesimpulan, menghasilkan produk, untuk dapat mencapai itu semua harus dirancang perangkat pembelajaran yang benar-benar mampu memecahkan masalah. Menurut Treffers (Agung, 2010: 12), pembelajaran matematika adalah aktivitas mengkontruksi pengetahuan matematika. Pemilihan model pembelajaran yang tepat dapat mewujudkan proses belajar mengajar yang dapat mengkontruksi pengetahuan peserta didik mengenai materi pelajaran matematika. Dengan demikian, 


\section{ELSE (Elementary School Education Jaurnal)}

Volume 3 Nomor 1 Februari 2019

P-ISSN: 2581-1800 E-ISSN: 2597-4122

Email: else@um-surabaya.ac.id

diharapkan perangkat pembelajaran yang digunakan dalam proses pembelajaran disusun dengan model pembelajaran yang tepat sesuai dengan karakteristik peserta didik khususnya pada pembelajaran matematika.

Hasil pengamatan pada pembelajaran matematika di kelas V SD Negeri 45 Kota Lubuklinggau. Proses pembelajaran yang diberikan guru kepada peserta didik, dimana seorang guru menjadi satu-satunya sumber informasi. Fakta tersebut menunjukkan bahwa proses Kegiatan Belajar Mengajar (KBM) menjadi pasif. Peserta didik hanya mendengarkan tanpa ikut aktif dalam KBM. Semakin lama peserta didik merasa jenuh dan bosan sehingga hasil belajar peserta didik mengalami penurunan. Hal itu disebabkan karena perangkat yang digunakan tersebut terdapat beberapa kekurangan diantaranya, model pembelajaran yang dirancang pada perangkat pembelajaran kurang cocok terhadap keefektifan proses pembelajaran matematika sehingga masih belum optimal dalam memfasilitasi perkembangan peserta didik.

Data analisis wawancara terhadap perangkat pembelajaran yang digunakan guru selama ini terlihat bahwa pada indikator kurang mewakili KD yang harus dikuasai peserta didik. Selanjutnya, tujuan pembelajaran kurang mengandung ABCD (Audience, Behavior, Condition, and Degree) sebagai syarat utama tujuan pembelajaran yang baik. Selain itu, model yang digunakan guru dalam RPP kurang mengaktifkan peserta didik dalam proses pembelajaran. Hal yang tidak kalah pentingnya adalah pada aspek penilaian. Penilaian yang dicantumkan kurang jelas prosedur dan teknik yang digunakan sehingga kurang tergambar kemampuan peserta didik yang akan diukur. Maka dari itu, dapat dikatakan bahwa RPP yang digunakan kurang dapat dimanfaatkan secara efektif.

Berdasarkan hasil wawancara dengan guru tersebut dapat dijelaskan dalam proses pembelajaran, masalah-masalah yang telah ada langsung diberikan kepada peserta didik dan peserta didik dituntut untuk memberikan jawaban yang benar. Guru juga kurang memberikan kesempatan kepada peserta didik untuk memberikan masalah yang sesuai dengan pengetahuan yang telah mereka miliki sebelumnya dan memperoleh pengetahuan baru dalam menyelesaikan masalah. Selain itu, dalam menyelesaikan masalah guru terbiasa memberikan contoh sehingga peserta didik langsung menyelesaikan masalah sesuai dengan contoh yang diberikan guru.

Guru juga menyatakan bahwa mereka kurang mengetahui apa pentingnya berpikir kreatif bagi peserta didik. Bagi guru dalam pembelajaran matematika materi habis. Sejalan 
dengan hal itu, guru dilapangan juga tidak pernah mengembangkan apakah perangkat pembelajaran yang digunakan saat ini telah dapat mengakomodasi peserta didik untuk dapat berpikir kreatif, sehingga aktivitas peserta didik juga kurang dalam pembelajaran matematika. Saat ditanya tentang perangkat pembelajaran, guru juga kurang kreatif dalam mengelola proses pembelajaran, sehingga peserta didik kurang mandiri, aktif, dan percaya diri. Hal ini juga berpengaruh terhadap hasil belajar peserta didik pada setiap ulangan harian pada semester 2 Tahun Pelajaran 2017/2018 dimana hasilnya masih di bawah standar ketuntasan belajar minimal yang ditetapkan oleh guru mata pelajaran yaitu 75 .

Salah satu cara yang dapat dilakukan guru dalam mengatasi permasalahan di atas adalah dengan menerapkan model pembelajaran Learning cycle 7E. Model pembelajaran dengan learning cycle $7 \mathrm{E}$ adalah suatu model pembelajaran yang berpusat pada peserta didik (student centered). Model learning cycle $7 \mathrm{E}$ merupakan rangkaian tahapan kegiatan (fase) yang diorganisasikan sedemikian rupa sehingga peserta didik dapat menguasai kompetensi-kompetensi yang harus dicapai dalam pembelajaran dengan jalan berperan aktif. Hal ini sesuai denagan pendapat Dasa (2005: 77) “learning cycle 7E juga merupakan model pembelajaran yang berbasis konstruktivistik yang dapat mengembangkan kinerja kelas "Kelas yang hidup" karena selalu menekankan peserta didik untuk mengkonstruksi sendiri pengetahuannya dan guru lebih berperan sebagai fasilitator bukan sebagai sumber info".

RPP merupakan salah satu alternatif yang tepat, karena dapat disesuaikan dengan model pembelajaran learning cycle 7E. Model learning cycle 7E merupakan model pembelajaran yang berbasis konstruktivisme yang terdiri dari tujuh fase berupa elicit, engage, explore, explain, elaborate, evaluate, dan extend yang terorganisasi dan berpusat pada siswa sehingga siswa secara aktif menemukan konsep sendiri dan mengkontruksi pengetahuan sendiri dalam pelajaran matematika. RPP dengan learning cycle 7E adalah perangkat yang sesuai dengan salah satu karakteristik pada kurikulum KTSP yaitu untuk melakukan pembelajaran yang berbasis pada pembelajaran konstruktivistik. Berdasarkan paparan di atas, penulis ingin melakukan penelitian dengan judul, "Pengembangan RPP Matematika Berbasis Model Learning cycle 7E Untuk Siswa Kelas V Sekolah Dasar”. yang valid, praktis, dan efektif. 


\section{METODE PENELITIAN}

Model pengembangan dalam penelitian ini mengikuti model umum desain penelitian menurut Plomp (2013:19) yang terditi atas 3 fase yaitu preliminary research, prototyping phase, dan assesment phase. Evaluasi dilakukan disemua fase pengembangan. Evaluasi mempunyai fungsi yang berbeda pada setiap siklus pengembangan. Tahap awal, evaluasi yang dilakukan difokuskan pada validasi isi. Pada tahap pembuatan prototipe, evaluasi difokuskan pada relevansi (validasi isi), konsistensi (validitas konstruk) dan praktikalitas. Tahap selanjutnya difokuskan pada praktikalitas dan efektivitas ketika produk tersebut diujicoba.

Pada tahap Preliminary research dilakukan identifikasi masalah dan kebutuhan dalam pelaksanaan pembelajaran di sekolah dasar. Ada empat langkah pokok dalam tahap ini, yaitu, analisis kurikulum, analisis konsep, analisis peserta didik, dan analisis perangkat pembelajaran yang digunakan di lapangan.

Berdasarkan hasil analisis pendahuluan dilakukan prototyping phase. Tahap ini terdiri atas prototipe 1 , prototipe 2 , prototipe 3 , dan prototipe 4 . Pada setiap prototipe dilakukan evaluasi dan revisi dengan tujuan menghasilkan RPP matematika dengan learning cycle $7 \mathrm{E}$ yang berkualitas tinggi. Pada tahap ini diperoleh data validitas dan praktikalitas. Data validitas diperoleh dari penilain pakar dengan menggunkan lembar validasi. Uji coba dalam penelitian pengembangan ini dilakukan terhadap siswa kelas $\mathrm{V}$ SD Negeri 45 Kota Lubuk linggau. Uji coba ini dilakukan untuk melihat praktikalitas RPP matematika dengan learning cycle 7E yang telah dikembangkan.

Pada tahap assesment, diuji efektivitas produk yang dihasilkan. Efektivitas produk artinya suatu ukuran yang menyatakan ada atau tidaknya efek atau pengaruh dari produk yang dikembangkan terhadap pengguna. Aspek efektivitas yang diamati dalam proses pembelajaran yang menggunakan RPP matematika berbasis model learning cycle 7E adalah aktivitas dan hasil belajar siswa setelah mengikuti proses pembelajaran dengan menggunakan bahan ajar yang telah dikembangkan. Pada tahap ini dilakukan evaluasi untuk mengetahui apakah RPP matematika berbasis model learning cycle 7E efektif untuk meningkatkan hasil belajar dan memicu aktivitas positif siswa. Untuk melihat efektivitas pada tahap assesment stage, RPP matematika berbasis model learning cycle 7E diimplementasikan di SD Negeri 45 Kota Lubuklinggau di kelas V pada tahun ajaran 2018/2019 Semester I. Data dalam penelitian ini diperoleh melalui instrumen. Instrumen 
pengumpulan data yang digunakan dalam penelitian berupa angket, pedoman wawancara, dan lembar observasi. Semua instrumen sebelum digunakan divalidasi oleh tiga orang validator ahli bahasa, teknologi pendidikan, dan matematika.

\section{HASIL DAN PEMBAHASAN}

\section{Hasil Penelitian}

Tahap analisis pendahuluan dilakukan sebelum mengembangkan dan merancang produk. Pada tahap ini dilakukan identifikasi masalah dan kebutuhan dalam pelaksanaan pembelajaran di Sekolah Dasar. Hasil analisis SK dan KD yang terdapat pada Standar Isi, dijabarkan menjadi indikator-indikator pencapaian pembelajaran dan tujuan pembelajaran. Isi kurikulum tersebut dinilai sudah baik untuk mencapai tujuan pembelajaran sehingga tidak dilakukan perubahan urutan KD karena telah menjabarkan materi yang sesuai dalam mengembangkan isi perangkat pembelajaran. Hasil analisis konsep pada hasil perumusan indikator dan analisis silabus mata pelajaran matematika kelas V SD. Materi disusun secara sistematis dengan menggunakan peta konsep sehingga materi yang akan dibahas dapat dilihat dengan spesifik. Hasil analisis karakteristik peserta didik yang dilakukan adalah usia peserta didik kelas V SD Negeri 45 Kota Lubuklinggau. Peserta didik berada pada usia 11-12 tahun. Kemampuan peserta didik kelas V di sekolah ini rata-rata sedang berdasarkan hasil wawancara dengan guru pada analisis pendahuluan. Hal ini dapat disimpukan dari peringkat sekolah dalam kecamatan. Peserta didik di sekolah ini telah mampu beragumentasi, dan sudah memiliki struktur bahasa yang kompleks serta mampu memahami berbagai aturan tata bahasa yang baik dan benar. Hasil analisis RPP yang digunakan guru di lapangan terlihat bahwa pada indikator kurang mewakili KD yang harus dikuasai peserta didik. Selanjutnya, tujuan pembelajaran kurang mengandung ABCD (Audience, Behavior, Condition, and Degree) sebagai syarat utama tujuan pembelajaran yang baik. Selain itu, model yang digunakan guru dalam RPP kurang mengaktifkan peserta didik dalam proses pembelajaran. Hal yang tidak kalah pentingnya adalah pada aspek penilaian. Penilaian yang dicantumkan kurang jelas prosedur dan teknik yang digunakan sehingga kurang tergambar kemampuan peserta didik yang akan diukur. Maka dari itu, dapat dikatakan bahwa RPP yang digunakan kurang dapat dimanfaatkan secara efektif.

Kegiatan selanjutnya yang dilakukan setelah tahap pendahuluan adalah merancang dan mengembangkan prototipe RPP matematika berbasis model learning cycle 7E. 
Prototipe yang dirancang adalah untuk materi bangun datar dan bangun ruang. Hasil rancangan prototipe awal ini diberi nama prototipe Berikut ini akan diuraikan karakteristik RPP matematika berbasis model learning cycle 7E yang telah dirancang. RPP disusun secara lengkap dan sistematis dengan mengacu pada. Komponen RPP mengacu pada Permendiknas No.41 tahun 2007 tentang Standar Proses, sedangkan prosedur pengambangannya mengacu pada petunjuk teknis pengembangan RPP yang dikeluarkan oleh Kemendiknas Ditjen Manajemen Dikdasmen tahun 2010. Berdasarkan analisis SK dan KD, maka dilahirkan indikator pencapaian kompetensi yang dibagi ke dalam pembelajaran. Setiap pembelajaran dikembangkan dengan melihat tiga kegiatan utama, yaitu kegiatan awal, kegiatan inti, dan kegiatan akhir.

Perancangan RPP dilakukan dengan memuat tahapan model learning cycle 7E yang digunakan pada masing-masing pembelajaran sehingga dapat menggambarkan langkahlangkah yang terstruktur secara sistematis. Nilai rata-rata validasi RPP dari keseluruhan validator dapat dilihat pada tabel 1.

Tabel 1. Hasil Validasi RPP Matematika Berbasis Model Learning Cycle 7E

\begin{tabular}{cccc}
\hline No & Validator & $\begin{array}{c}\text { Rata-rata } \\
(\boldsymbol{\%})\end{array}$ & Kateg ori \\
\hline 1 & Validator I & 96 & Sangat Valid \\
2 & Validator II & 88 & Sangat Valid \\
3 & Validator III & 92 & Sangat Valid \\
\hline & Rata-rata & $\mathbf{9 2}$ & Sangat Valid \\
\hline
\end{tabular}

Prototipe diuji sesuai model pengembangan Plomp pada tahap prototyping phase. Hasil Uji coba produk diawali dengan one to one evaluation (Prototipe 2), one to one evaluation dilakukan dengan memberikan LKS pada RPP (Prototype 2) kepada dua orang peserta didik. Peserta didik ini diminta untuk mencoba mengisi LKS sesuai dengan kemampuan mereka masing-masing. Setelah peserta didik mengerjakan LKS, peserta didik diberikan angket respon peserta didik dan pedoman wawancara repon peserta didik.

Angket respon peserta didik dan pedoman wawancara respon peserta didik diberikan kepada peserta didik untuk mengetahui pendapat peserta didik tentang tingkat kepraktisan RPP matematika berbasis model learning cycle 7E yang telah dirancang. Secara ringkas hasil lembar praktikalitas respon peserta didik terhadap RPP matematika berbasis model learning cycle 7E dapat dilihat pada tabel 2. 
Tabel 2. Hasil Analisis Angket Respon Peserta didik (One to One Evaluation)

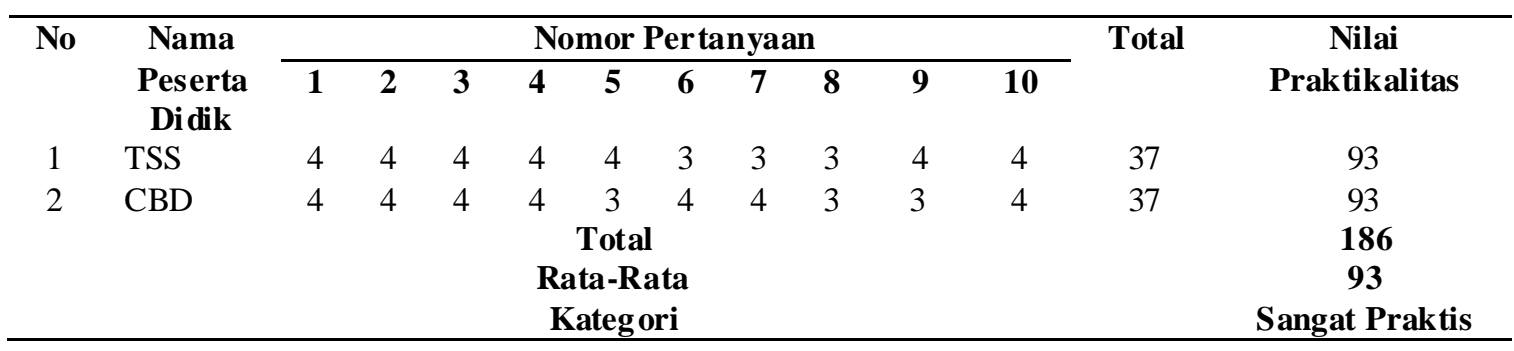

Pada tabel 2 di atas terlihat rata-rata praktikalitas RPP matematika berbasis model learning cycle 7E pada tahap one to one evaluation adalah $93 \%$ dengan kategori sangat praktis. Hasil wawancara peserta didik menyatakan tertarik belajar dengan RPP matematika berbasis model learning cycle 7E yang telah dirancang karena berwarna dan kegiatan percobaannya juga menarik. Peserta didik juga menyatakan memahami materi yang ada dalam LKS dan tidak terlalu banyak membutuhkan arahan untuk menyelesaikan setiap kegiatan belajar. Berdasarkan permasalahan yang ditemukan, maka dilakukan revisi terhadap RPP matematika berbasis model learning cycle 7E.

Hasil Evaluasi Small Group (Prototipe 3) Prototype 2 yang telah direvisi sesuai dengan hasil one to one evaluation disebut prototipe 3. Prototipe 3 juga dievaluasi untuk melihat kepraktisannya. Evaluasi dilakukan dengan cara melakukan small group discussion atau evaluasi kelompok kecil sebanyak satu kali pertemuan dengan mempraktekkan RPP matematika berbasis model learning cycle 7E yang telah dirancang kepada empat orang peserta didik kelas V SD Negeri 45 Kota Lubuklinggau tentang materi bangun datar yang berasal dari kemampuan tinggi, sedang, dan rendah.

Untuk menilai kepraktisan RPP matematika berbasis model learning cycle 7E juga menggunakan angket respon peserta didik dan pedoman wawancara. Secara ringkas hasil lembar angket praktikalitas RPP matematika berbasis model learning cycle 7E dari peserta didik dapat dilihat pada tabel 3. 
Tabel 3. Hasil Analisis Angket Respon Peserta Didik (Small Group)

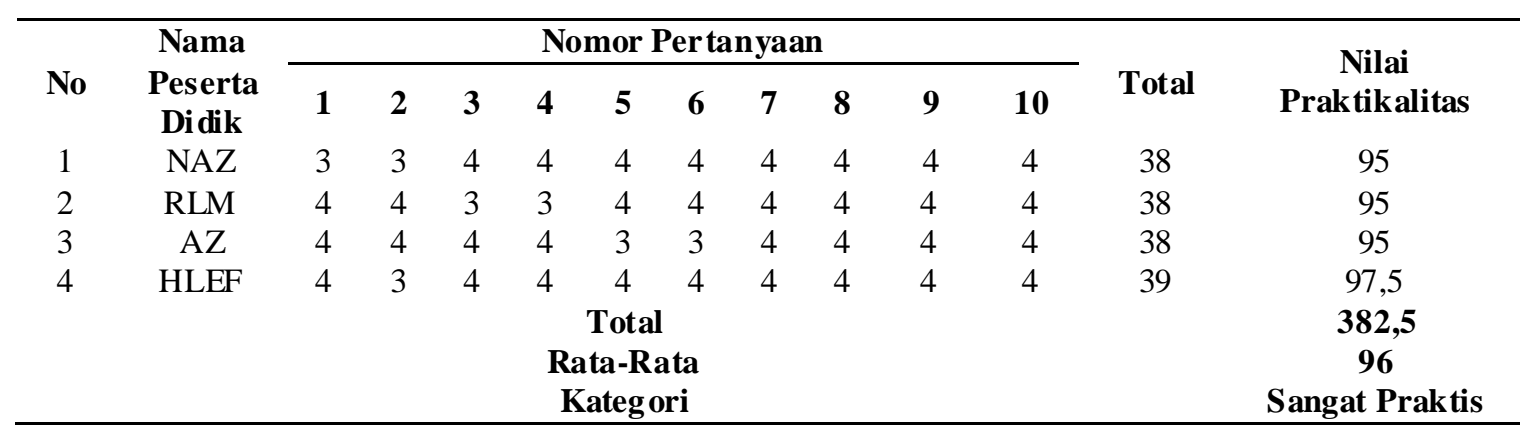

Pada tabel 3 di atas terlihat rata-rata praktikalitas RPP matematika berbasis model learning cycle 7E pada tahap small group yang terdiri dari 4 orang peserta didik adalah 96\% dengan kategori sangat praktis. Hasil wawancara peserta didik menyatakan tertarik belajar dengan RPP matematika berbasis model learning cycle 7E yang telah dirancang karena berwarna dan kegiatan percobaannya juga menarik. Peserta didik juga menyatakan memahami materi yang ada dalam LKS dan tidak terlalu banyak membutuhkan arahan untuk menyelesaikan setiap kegiatan belajar.

Hasil Evaluasi Field test (Prototipe 4), Setelah dilakukan revisi, selanjutnya RPP matematika berbasis model learning cycle 7E diujicobakan di SD Negeri 45 Kota Lubuklinggau dengan jumlah peserta didik sebanyak 25 orang. Field test dilakukan dengan cara meminta guru kelas V mempraktekkan RPP matematika berbasis model learning cycle $7 \mathrm{E}$ yang telah dirancang dalam pembelajaran matematika pada materi bangun datar trapesium dan layang-layang. Data hasil uji coba yang diperoleh, diuraikan sebagai berikut. Hasil angket praktikalitas menurut respon guru data uji praktikalitas RPP matematika berbasis model learning cycle $7 \mathrm{E}$ oleh guru terhadap pembelajaran matematika diperoleh melalui angket respon guru. Data angket respon guru diperoleh dari guru kelas V SD Negeri 45 Kota Lubuklinggau.

Hasil uji praktikalitas dengan menggunakan angket praktikalitas respon guru memberikan nilai praktikalitas 91\%. Berdasarkan kriteria yang telah dibuat, maka praktikalitas SD Negeri 45 Kota Lubuklinggau dinyatakan sangat praktis. Terlihat dari angket yang diisi, menurut guru SD Negeri 45 Kota Lubuklinggau dapat digunakan, menarik, bisa dipahami dengan baik, dapat memotivasi peserta didik belajar matematika dan menemukan konsep dengan baik. Hasil angket praktikalitas menurut respon peserta didik, praktikalitas RPP matematika berbasis model learning cycle 7E untuk peserta didik 
diuji setelah peserta didik belajar menggunakan RPP matematika berbasis model learning cycle 7E. Angket praktikalitas diberikan kepada peserta didik SD negeri 45 Kota Lubuklinggau yang berjunlah 25 orang. Hasil tingkat kepraktisan LKS matematika dengan learning cycle 5E model Lorascbach menurut respon peserta didik adalah 92,5\%. Jadi, dapat disimpulkan bahwa LKS matematika dengan learning cycle 5E model Lorscbach dinyatakan sangat praktis.

Hasil observasi pelaksanaan pembelajaran berdasarkan pengamatan, tidak ada revisi yang peneliti lakukan terhadap LKS dengan learning cycle 5E model Lorscbach. Namun, peneliti menyampaikan kepada guru agar membantu peserta didik memahami tujuan pembelajaran dan tidak lupa menyampaikan waktu yang dibutuhkan peserta didik untuk menyelesaikan kegiatan belajar pada pertemuan selanjutnya. Hasil Wawancara dengan guru dan peserta didik, pada hasil wawancara yang dilakukan dengan guru, terungkap bahwa RPP matematika berbasis model learning cycle 7E ini sudah cukup baik untuk diterapkan, setiap langkah kegiatannya dinilai menarik oleh guru dan dapat meningkatkan aktivitas peserta didik selama proses pembelajaran. Menurut guru, perangkat pembelajaran ini juga akan sangat baik diterapkan untuk materi matematika yang lainnya karena dapat meningkatkan minat belajar peserta didik. Akan tetapi, guru merasa waktu yang disediakan untuk menyelesaikan kegiatan belajar pada LKS masih sedikit kurang dan perlu ditambah.

Pada hasil wawancara dengan peserta didik, dapat dilihat bahwa rata-rata peserta didik senang belajar menggunakan RPP matematika berbasis model learning cycle 7E karena tampilan LKS yang menarik dan kegiatan-kegiatan latihan yang menyenangkan. Peserta didik juga merasa tidak membutuhkan banyak arahan dari guru selama menyelesaikan kegiatan dalam LKS karena petunjuk dan langkah kerja yang diberikan sudah cukup jelas. Selain itu, peserta didik mengakui ada manfaat yang dirasakannya setelah belajar dengan menggunakan RPP matematika berbasis model learning cycle 7E, peserta didik merasa lebih memahami materi dan dapat mencoba menerapkan konsep yang sesuai dengan materi yang telah dipelajari.

Hasil assesment phase (tahap penilaian), perangkat pembelajaran yang sudah dinyatakan praktis, selanjutnya diujicobakan pada peserta didik kelas V SD Negeri 45 Kota Lubuklinggau untuk melihat keefektivannya. Keefektivan LKS dilihat dari aktivitas peserta didik dan hasil belajar. Tahap ini menjadi hasil akhir rangkaian pengembangan RPP 
matematika berbasis model learning cycle 7E. Tahap ini dilakukan sebanyak enam kali pertemuan, dan dapat dilihat pada tabel 4.

Tabel 4. Hasil Pengamatan Aktivitas Peserta Didik

\begin{tabular}{clc}
\hline No & Aspek yang Diamati & $\begin{array}{c}\text { Persentase Akti vitas } \\
\text { Peserta Di dik }\end{array}$ \\
\hline 1 & Memperhatikan dan mendengar penjelasan guru & 80 \\
2 & Memperhatikan perangkat pembelajaran & 80 \\
3 & Mengerjakan langkah-langkah yang terdapat dalam & 80 \\
4 & perangkat pembelajaran & 80 \\
5 & Mengajukan pertanyaan & 80 \\
& Rata-Rata & $\mathbf{8 0}$ \\
& Kategori & Sangat Efektif
\end{tabular}

Hasil belajar pada ranah kognitif diperoleh dari soal tes dalam bentuk soal isian. Tes dilakukan setelah selesai pembelajaran menggunakan RPP matematika berbasis model learning cycle 7E. Soal tes dibuat berdasarkan kisi-kisi soal yang kemudian diujicobakan kepada peserta didik kelas V SDN 45 Kota Lubuklinggau. Perolehan nilai yang didapat dari 25 orang peserta didik yang mengerjakan soal tes untuk menilai efektivitas RPP matematika berbasis model learning cycle 7E dari ranah kognitif. Dapat dilihat bahwa dari KKM 75 yang telah ditetapkan sekolah, 21 orang peserta didik mendapatkan kategori tuntas dan hanya 3 orang peserta didik yang tidak tuntas. Rata-rata ketuntasan klasikal yang diperoleh adalah $87,5 \%$. Hasil akhir yang didapatkan tersebut telah sesuai dengan tujuan yang telah ditetapkan yaitu $85 \%$ peserta didik tuntas belajarnya, sehingga apabila dilihat secara klasikal hasil belajar matematika ranah kognitif dengan menggunakan RPP matematika berbasis model learning cycle 7E telah dikatakan tuntas.

\section{Pembahasan}

Penelitian ini merupakan penelitian pendidikan dengan model design research yang mengembangkan suatu produk. Model pengembangan yang digunakan dalam penelitian ini diadaptasi dari model McKenny. Model ini terdiri atas 3 tahap, yaitu (1) preliminary research atau analisis pendahuluan, (2) prototyping phase atau tahap perancangan, dan (3) assesment phase atau tahap penilaian (Plomp dan Nieveen, 2013:19). Produk yang dikembangkan dalam penelitian ini adalah RPP matematika berbasis model learning cycle 7E untuk kelas V SD. Produk tersebut telah diujicobakan pada pesserta didik kelas V SD Negeri 45 Kota Lubuklinggau dengan jumlah peserta didik 25 orang. Paparan pembahasan 
mengenai hasil penelitian pengembangan yang telah dilakukan akan diuraikan lebih lanjut terutama yang berkaitan dengan validitas, praktikalitas, dan efektivitas produk yang dikembangkan. Untuk lebih jelasnya pembahasan tersebut diuraikan sebagai berikut. Validitas RPP matematika berbasis model learning cycle 7E yang dikembangkan dinyatakan valid apabila telah memenuhi syarat-syarat yang telah ditetapkan baik secara isi maupun konstruk, sesuai dengan pendapat Plomp (2013:29) karakteristik dari produk yang dikatakan valid apabila produk tersebut komponen-komponennya didasarkan pada prinsip pengetahuan.

Validitas RPP matematika berbasis model learning cycle 7E melibatkan lima orang validator, sesuai dengan pendapat Sugiyono (2009:414) bahwa validasi produk dapat dilakukan oleh beberapa pakar atau tenaga ahli yang sudah berpengalaman untuk menilai produk baru yang dirancang, sehingga selanjutnya dapat diketahui kelemahan dan keunggulannya. Hasil validasi dari ahli tersebut dikumpulkan kemudian dianalisis untuk dicari rata-rata dari masing-masing indikator dan masing-masing aspek. Berdasarkan analisis kevalidan RPP matematika berbasis model learning cycle 7E oleh validator dapat disimpulkan secara keseluruhan RPP matematika berbasis model learning cycle 7E yang dikembangkan sudah termasuk kategori sangat valid dengan persentase nilai rata-rata keseluruhan sebesar 92\%. Penilaian yang valid terhadap RPP matematika berbasis model learning cycle 7E yang dikembangkan menandakan bahwa perangkat pembelajaran dapat digunakan sebagai sumber belajar matematika untuk guru dan peserta didik SD kelas V pada semester satu.

Praktikalitas RPP matematika berbasis model learning cycle 7E dikatakan praktis, jika guru dan peserta didik dapat menggunakan perangkat pembelajaran tersebut untuk melaksanakan pembelajaran, tanpa banyak masalah. Uji praktikalitas ini dilakukan untuk mengungkap bagaimana kemudahan penggunaan perangkat pembelajaran, kesesuaian waktu dengan banyak dan bentuk tugas, daya tarik/minat guru dan peserta didik terhadap perangkat pembelajaran dan keterbacaan perangkat pembelajaran oleh guru dan peserta didik. Uji praktikalitas dilakukan melalui beberapa kegiatan, yaitu one to one evaluation, small group dan field test.

Dari hasil penelitian tersebut dapat dilihat bahwa peserta didik menunjukkan motivasi yang bagus setelah belajar dengan RPP matematika berbasis model learning cycle 7E, karena dengan RPP matematika berbasis model learning cycle 7E peserta didik 


\section{ELSE (Elementary School Education Jaurnal)}

Volume 3 Nomor 1 Februari 2019

P-ISSN: 2581-1800 E-ISSN: 2597-4122

Email: else@um-surabaya.ac.id

dilibatkan secara langsung dalam proses pembelajaran Meskipun demikian, ada beberapa bagian dari LKS tersebut yang membuat peserta didik kebingungan. Oleh sebab itu, dilakukan sedikit perbaikan pada LKS pada tahap uji lapangan ini, namun demikian secara umum dapat disimpulkan dari hasil analisis angket respon guru dan peserta didik, serta wawancara yang dilakukan bahwa RPP matematika berbasis model learning cycle 7E yang dikembangkan sudah dikategorikan praktis untuk digunakan oleh guru dan peserta didik.

Efektivitas RPP matematika berbasis model learning cycle 7E yang dikembangkan dapat dilihat dari aktivitas dan hasil belajar peserta didik. Aktivitas peserta didik selama proses pembelajaran merupakan kegiatan atau perilaku yang terjadi selama proses pembelajaran dengan menggunakan RPP matematika berbasis model learning cycle 7E. Aktivitas yang diamati untuk melihat efektivitas RPP matematika berbasis model learning cycle $7 \mathrm{E}$ adalah jenis aktivitas peserta didik yang diamati terdiri dari memperhatikan dan mendengarkan penjelasan guru, memperhatikan perangkat pembelajaran, mengerjakan langkah-langkah yang terdapat dalam perangkat pembelajaran, mengajukan pertanyaan, dan menanggapi.

Hasil analisis aktivitas peserta didik secara keseluruhan selama proses pembelajaran menunjukkan bahwa aktivitas peserta didik berada dalam kategori sangat efektif dengan nilai rata-rata $81,2 \%$. Dari 25 orang peserta didik yang telah mengikuti pembelajaran dengan menggunakan RPP matematika berbasis model learning cycle 7E terlihat bahwa peserta didik umumnya melakukan aktivitas pembelajaran yang cukup bervariasi. Sejalan dengan pendapat Hollingsworth dan Lewis (2008:viii) bahwa peserta didik belajar secara aktif ketika mereka terlibat secara terus menerus, baik mental maupun fisik. Pembelajaran aktif melibatkan pembelajaran yang terjadi ketika peserta didik bersemangat siap secara mental, dan bisa memahami pengalaman yang dialami

Tes hasil belajar digunakan untuk mengetahui keefektifan proses pembelajaran setelah menggunakan RPP matematika berbasis model learning cycle 7E. Penilaian hasil belajar dilakukan pada ranah kognitif. Analisis hasil belajar digunakan untuk mengetahui kentutasan belajar peserta didik. Tes hasil belajar yang dikembangkan disesuaikan dengan jenjang kemampuan kognitif. Trianto (2011:235) menyatakan bahwa,“Tes hasil belajar merupakan butir tes yang digunakan untuk mengetahui hasil belajar peserta didik setelah mengikuti kegiatan pembelajaran". Untuk penilaian ranah kognitif dilakukan dengan pemberian tes formatif yang dilakukan setelah kegiatan pembelajaran dilaksanakan. 
Berdasarkan analisis data hasil tes akhir didapat nilai rata-rata peserta didik 87,5\%. Nilainya diatas KKM yang ditentukan sekolah yaitu $>75$. Dengan demikian perangkat pembelajaran matematika dengan learning cycle 5E model Lorscbach sudah bisa dikatakan efektif. Hasil penelitian yang dilakukan oleh Acisli dan Turgut (2011:564) juga menyatakan bahwa,"The experimental group has a higher average in the scores than the control group. Students in the experimental group are more succesful than those in the control group. Use of the LC 7E Model helps students learn the main points and concepts more easily".

Hasil penelitian tersebut menunjukkan bahwa nilai yang diperoleh kelas eksperimen yang menerapkan learning cycle 7E lebih tinggi dibandingkan kelas kontrol, ini dikarenakan penggunaan model learning cycle 7E dapat membantu siswa memahami poin utama dan konsep lebih mudah. Dengan demikian dapat disimpulkan bahwa pembelajaran dengan menggunakan RPP matematika berbasis model learning cycle 7E sangat efektif digunakan dalam pembelajaran karena dapat meningkatkan hasil belajar peserta didik.

\section{KESIMPULAN DAN SARAN}

Penelitian ini merupakan penelitian pengembangan yang menghasilkan RPP matematika berbasis model learning cycle 7E. Berdasarkan hasil pengembangan dan uji coba RPP matematika berbasis model learning cycle 7E model Lorscbach diperoleh kesimpulan sebagai berikut. Telah dihasilkan RPP matematika berbasis model learning cycle 7E dengan kategori rata-rata hasil validasi keseluruhan $92 \%$ dengan kategori sangat valid, berdasarkan hasil validasi perangkat pembelajaran oleh validator ahli. Hasil yang didapat memberi gambaran bahwa perangkat pembelajaran yang dikembangkan telah valid dan dapat digunakan dalam pembelajaran matematika.

Praktikalitas RPP matematika berbasis model learning cycle 7E secara keseluruhan sangat praktis. Praktikalitas RPP matematika diketahui dari hasil angket respon siswa yang telah mengikuti pembelajaran dengan menggunakan RPP matematika berbasis model learning cycle 7E dengan rata-rata 92,5\%, angket respon guru yang menggunakan RPP matematika berbasis model learning cycle 7E dengan rata-rata sebesar $97 \%$ serta wawancara peserta didik dan guru yang tertarik mengajar dan belajar menggunakan RPP matematika berbasis model learning cycle 7E. Hasil ini memberi gambaran bahwa 


\section{ELSE (Elementary School Education Journal)}

Volume 3 Nomor 1 Februari 2019

P-ISSN: 2581-1800 E-ISSN: 2597-4122

Email: else@um-surabaya.ac.id

penggunaan perangkat pembelajaran oleh guru sangat praktis dan dapat membantu meningkatkan minat siswa dalam pembelajaran matematika.

Efektivitas penggunaan RPP matematika berbasis model learning cycle 7E dapat diketahui melalui pengamatan aktivitas belajar peserta didik, dan hasil belajar peserta didik. Aktivitas belajar peserta didik selama belajar dengan menggunakan perangkat pembelajaran ini sangat efektif dengan rata-rata $80 \%$ dan hasil belajar siswa dengan ratarata $87,5 \%$ dan berada diatas KKM sekolah yaitu $>75$. Hasil pengamatan ini memberi gambaran bahwa penggunaan RPP matematika berbasis model learning cycle 7E sudah efektif dilaksanakan.

\section{DAFTAR PUSTAKA}

Depdiknas. 2006. Panduan Penyusunan Kurikulum Tingkat Satuan Pendidikan. Jakarta: Depdiknas.

Depdiknas. 2008. Pengembangan LKS. Jakarta: Departemen Pendidikan Nasional.

Ergin, I. 2012. Constructivist Approach Based 7E Model And Usability Instructional Math. Turkish Military Academi. Turky. Journal Math Education 6 (1) 2012 online at http//www.lajpe.org. [diakses tanggal 7 April 2018].

Hamalik, O. 2008. Proses Belajar Mengajar. Jakarta: PT. Bumi Aksara.

Mulyasa, E. 2009. Implementasi Kurikulum Tingkat Satuan Pendidikan Kemandirian Guru dan Kepala Sekolah. Jakarta: Bumi Aksara.

Plomp \& Neeven. (2013). Educational Design: Introduction. From Tjeerd Plomp (eds). Educational \&Training System Design: Introduction. Design of Education and Training (in Dutch).Utrecht (the Netherlands): Lemma. Netherland. Faculty of Educational Science and Technology, University of Twente.

Prastowo A. 2011. Panduan Kreatif Membuat LKS Inovatif. Yogyakarta: Diva Press.

Purwanto, D. 2014. Pengembangan Perangkat Pembelajaran (Silabus, RPP, PHB, Perangkat pembelajaran). Yogyakarta: Gava Media.

Riduwan \& Sunarto. 2012. Pengantar Statistika. Bandung: Alfabeta.

Sanjaya, Wina. 2009. Perencanaan dan Desain Sistem Pembelajaran. Jakarta: Prenada Media Group.

Sugiyono. 2011. Metode Penelitian Kuantitatif Kualitatif dan R\&D. Bandung: Alfabeta. 
Trianto. 2010. Model Pembelajaran Terpadu: Konsep, Strategi dan Implementasinya dalam Kurikulum Satuan Pendidikan (KTSP). Jakarta: Bumi Aksara.

Utari, dkk. 2013. Pengembangan Perangkat Pembelajaran Matematika Dengan learning cycle $7 E$ pada Materi Bangun Ruang untuk Kelas V SDN 02 Bekasi. Tahun Ajaran 2013/2014. Jurnal Matematika Volume 9 No. 2 Juli 2014.

Van den Akker, J. (2014). Principles and Methods of Development Research. Pada J. van den Akker, R.Branch, K. Gustafson, Nieven, dan T. Plomp (eds), Design Approaches and Tools in Education and Training (pp. 1-14). Dortrech: Kluwer Academic Publishers. 